\title{
High irradiance and temperature inhibit the germination of spores of the fern Rumohra adiantiformis (Forst.) Ching (Dryopteridaceae) ${ }^{1}$
}

\author{
FRANCIS R. BRUM² and ÁUREA M. RANDI ${ }^{2,3}$
}

(received: August 15, 2001; accepted: June 5, 2002)

\begin{abstract}
ABSCTRACT - (High irradiance and temperature inhibit the germination of spores of the fern Rumohra adiantiformis (Forst.) Ching (Dryopteridaceae)). Rumohra adiantiformis (Forst.) Ching is a fern (Dryopteridaceae) which is used to compose floral arrangements. Fertile fronds were harvested in the "Permanently Protected Area" of Ilha Comprida, São Paulo, Brazil. Sterilized spores were germinated in Mohr liquid medium modified by Dyer. The effect of 72\%, 54\%, 17\% and 9\% of total irradiance on germination under field conditions, was analyzed. Experiments were carried out in March (I), April (II) and August of 2000 (III). Under 54\% and 72\% of total irradiance in Experiment I (March) the germination was completely inhibited and partially inhibited under $72 \%$ of total irradiance in Experiment II (April). The lowest mean germination time ( $\overline{\mathrm{t}})$ was observed under 9\% of total irradiance in Experiments II (11.62 days) and III (8.80 days) respectively, followed by $17 \%$ in Experiment III (10.12 days) and 9\% of total irradiance in the Experiment I (11.62 days ). The effect of temperatures of $15 \pm 1,20 \pm 1,25 \pm 1$ and $30 \pm$ $1{ }^{\circ} \mathrm{C}$ on germination was also analyzed. The lowest mean germination time ( 7.93 days) was observed at $25 \pm 1^{\circ} \mathrm{C}$ followed by 20 $\pm 1{ }^{\circ} \mathrm{C}$. The highest mean germination time was observed at $15 \pm 1{ }^{\circ} \mathrm{C}$ (12.10 days) followed by $30 \pm 1{ }^{\circ} \mathrm{C}(10.63$ days $)$, which inhibited germination. The germination of $R$. adiantiformis was photoinhibited by high irradiance and partially inhibited by the highest temperature tested.
\end{abstract}

RESUMO - (Alta irradiância e temperatura inibem a germinação de esporos da samambaia Rumohra adiantiformis (Forst.) Ching (Dryopteridaceae)). Rumohra adiantiformis (Forst.) Ching é uma pteridófita (Dryopteridaceae) usada para compor arranjos florais. Frondes férteis foram coletadas na "Área de Preservação Permanente” Ilha Comprida, São Paulo, Brasil. Esporos esterilizados germinaram em meio de Mohr modificado por Dyer. O efeito de 72\%, 54\%, 17\% e 9\% de irradiância total sobre a germinação em condições ambientais, foi analisado. Experimentos foram conduzidos em março (I), abril (II) e agosto (III) de 2000. Sob 54\% e 72\% de irradiância total, em março a germinação foi completamente inibida e parcialmente inibida sob $72 \%$ de irradiância em abril. O menor tempo médio de germinação ( $\overline{\mathrm{t}}$ ) foi observado sob $9 \%$ de irradiância total nos Experimentos II (7,93 dias ) e III (8,80 dias), respectivamente, seguidos de 17\% no Experimento III (10,12dias ) e $9 \%$ de irradiância solar total no Experimento I (11,62 dias). O efeito de temperaturas de $15 \pm 1,20 \pm 1,25 \pm 1$ e $30 \pm 1{ }^{\circ} \mathrm{C}$ sobre a germinação também foi analisado. O menor tempo médio de germinação (7,93 dias) foi observado a $25 \pm 1{ }^{\circ} \mathrm{C}$ seguido de 20 $\pm 1{ }^{\circ} \mathrm{C}$. O maior tempo médio de germinação foi observado a $15 \pm 1{ }^{\circ} \mathrm{C}\left(12,10\right.$ dias) seguido de $30 \pm 1{ }^{\circ} \mathrm{C}$ (10,63 dias), que inibiu a germinação. A germinação de $R$. adiantiformis foi fotoinibida pela alta irradiância e parcialmente inibida pela temperatura mais alta testada.

Key words - Germination, irradiance, Rumohra adiantiformis, temperature

\section{Introduction}

Rumohra adiantiformis (Forst.) Ching is a fern (Dryopteridaceae) belonging to the order Filicales, where all the plants are homosporous and originate green gametophytes with numerous rhizoids on the inferior central surface. This fern is a terrestrial species

\footnotetext{
1. Part of the MSc thesis of F.R. Brum.

2. Universidade Federal de Santa Catarina, Centro de Ciências Biológicas, Departamento de Botânica Laboratório de Fisiologia Vegetal, Programa de Pós-graduação em Biologia Vegetal, Campus Universitário, Caixa Postal 476, 88040-900 Florianópolis, SC, Brazil.

3. Corresponding author: amrandi@ccb.ufsc.br
}

growing in a variety of habitats, from bare sandy soil to areas with bushes, in forests or even on rocks. It occurs from sea level to altitudes above $2,400 \mathrm{~m}$, in the Peruvian Andes (Kato 1974, Tryon \& Tryon 1982).

This plant became one of the most popular in the composition of floral arrangements because of the exceptional period of life of the leaves after being cut and kept in a vase (Milton \& Moll 1988). The majority of the world's production of leaves of the fern takes place in Florida, where the cultivation is accomplished in controlled conditions (Stamps et al. 1994). However, in countries such as the Republic of South Africa and Brazil, where natural populations of the species exist, the extraction is done directly in the field (Milton \& Moll 1988). In relation to this aspect, little information 
exists in the world literature on the demography, production of fronds or effects of the crop on the demographic dynamics of the species. A study carried out in Cable Province, South Africa, showed that the average density of plants in 25 places investigated was of 4 per $\mathrm{m}^{2}$ (Milton \& Moll 1988). The commercial exploitation in the South of Africa showed that the retreat of fronds usually exceeded their production in the first year of use of the area. In the subsequent years, the extracted volume was smaller, and this decrease was correlated positively with the decrease in the size of the fronds (Milton \& Moll 1988). These data suggest that the potential of production of Rumohra in South Africa was overestimated grossly by the commercial exploitation. According to Milton \& Moll (1988) information about productivity of the plants, demography, ecology, physiology and life cycle are requirements for the establishment of a system of sustainable management.

Although the effects of light in promoting fern germination have been very well analyzed (Furuya 1983, 1985, Raghavan 1993), almost nothing is known about the effects of different irradiance on germination and early gametophyte development.

The temperature exercises influence on the effects of the light in the germination of fern spores. Towill (1978) observed that the germination of Onoclea sensibilis L. is controlled by the light and temperature and suggests that mild temperatures are necessary for the induction of the germination by altering the permeability of the membrane. Treatments of $40^{\circ} \mathrm{C}$ for 8 hours or more reduce the light sensitivity of $O$. sensibilis which can be reverted by incubation in darkness at $25{ }^{\circ} \mathrm{C}$ (Chen et al. 1979). Haupt (1990), studying the inhibition of the germination of Dryopteris paleacea (Sw.) Hand-Mazz. by high temperatures suggested that the temperature affects the germination by restricting the coupling phase, that is, the phase in which the phytochrome starts a reaction of translation of signs in chain.

This paper investigates the effects of temperature and irradiance on the germination of $R$. adiantiformis. It has the objective of understanding aspects of the physiology of germination for producing plants in order to assist in their yield and conservation in the environmental conditions of Brazil.

\section{Material and methods}

Fertile fronds of Rumohra adiantiformis (Forst.) Ching were harvested in the "Permanently Protected Area" of Ilha
Comprida, São Paulo state, south, Brazil, in July and August 1999, and March 2000. Following collection, fronds were air-dried in an oven at $30^{\circ} \mathrm{C}$ for three days on filter paper in order to induce dehiscence. The spores were removed and separated from sporangia by filtering through tissue paper, after which they were stored in glass jars under refrigeration at $7 \pm 1{ }^{\circ} \mathrm{C}$. In the present study, different treatments for decontamination were previously tested in spores collected in July and August, 1999, in order to define the best method of achieving total decontamination and high percentage of germination. The time of exposition and the dilutions of commercial bleach were varied, and the germination was monitored. The best sterilization method for this species and for this batch of spores was that which employed surface sterilization by 10 minutes immersion in a $15 \%(\mathrm{v} / \mathrm{v})$ solution of commercial bleach (Q-Boa $\left.{ }^{\circledR}\right)$. After that, spores were filtered through sterile filter paper by vacuum and washing several times with sterile distilled water. For the germination tests, about $10 \mathrm{mg}$ of sterilized spores were sown in two conical flasks containing $20 \mathrm{ml}$ of autoclaved liquid mineral Dyer medium (Mohr 1956 modified by Dyer 1979) supplemented with Benomyl (Benlate ${ }^{\circledR}$ ) $0.01 \%$. The flasks were plugged with two layers of autoclaved transparent commercial polypropylene film $(7 \times 7 \mathrm{~cm})$ fixed with rubber band. All the procedures were carried out in a laminar hood. The effect of darkness on germination of $R$. adiantiformis was previously analyzed. For this test, spores collected in August (1999) were sown in four conical flasks: two were kept in light and two were covered with aluminum foil. The flasks with embedded spores were kept in a growth chamber at $25 \pm 1{ }^{\circ} \mathrm{C}$ under a 16 -hour photoperiod and photosynthetic photon flux density of $21 \mu \mathrm{mol} \cdot \mathrm{m}^{-2} \cdot \mathrm{s}^{-1}$ which was provided by cool white fluorescent tubes. After 16 days of cultivation, the germination in both treatments was analyzed and compared. For the study of the effects of different irradiance on germination, trays containing two conical flasks per treatment, in which surface sterilized spores (collected in March 2000) were sowing, as described before, were kept in $50 \mathrm{~cm}^{3}$ boxes covered with black shade netting which gave $72 \%, 54 \%, 17 \%$ and $9 \%$ total irradiance. The levels of irradiance inside the boxes were analyzed by a quantameter LICOR 250, provided by PAR sensor (400 to $700 \mathrm{~nm}$ ), in a typical March day at midday. The photosynthetic photon flux density in this situation reaches $1,400 \mu$ moles. $\mathrm{m}^{-2} \cdot \mathrm{s}^{-1}$ in Florianópolis, SC, south Brazil. Experiments were carried out in March (I), April (II) and August (III) to analyze the effect of different irradiance on germination under different field conditions. The averages of temperature in March ranged from 17 to $32{ }^{\circ} \mathrm{C}$, from 13 to $30^{\circ} \mathrm{C}$ in April and from 5 to 26 ${ }^{\circ} \mathrm{C}$ in August. For comparing the effect of temperatures on germination, two conical flasks containing mineral liquid medium in which surface sterilized spores (collected in March 2000) were sowing, were kept in a growth chamber under a 16-hour photoperiod as described before and the temperature 
was adjusted to $15 \pm 1,20 \pm 1,25 \pm 1$ and $30 \pm 1{ }^{\circ} \mathrm{C}$.

In this study, all the tests were completely randomized. The germination was scored every two days and two slides were analyzed from each flask per treatment, with 100 spores counted on each slide (four replications per treatment). The data was analyzed by Excel for Windows (Microsoft) and Statgraphics softwares. The results of germination are expressed as percentages, but for the statistical analysis they were submitted to arcsine transformation to normalize data. After angular transformation as suggested by Santana \& Ranal (2000), means of four replications per treatment, in each day of evaluation, were compared by Multiple Range Test (Tukey $p<0.05)$. The mean germination time was calculated for each replication per treatment according to the equation: $\overline{\mathrm{t}}=\sum(\mathrm{tn}) / \sum \mathrm{n}$ where $\mathrm{t}$ is the time in days starting from day 0 and $n$ is the number of spores completing germination on day $t$ (Labouriau 1983). These data were compared by Multiple Range Test.

\section{Results and Discussion}

Spores of Rumohra adiantiformis needs previous surface sterilization to avoid contamination during germination. The liquid mineral Dyer medium seems to be adequate for the germination of this species which reached almost $100 \%$ in 10 days of cultivation at $25 \pm$ $1{ }^{\circ} \mathrm{C}$ in growth chamber (figure 1). Spores of $R$. adiantiformis did not germinate in darkness after 16 days of cultivation. Rhaghavan (1989) reported that in general, liquid media were superior for fern spore germination and that it is likely that solid media prevents the breakage of spore coats. According to Camloh (1993), for spores of Platycerium bifurcatum (Cav.) C.

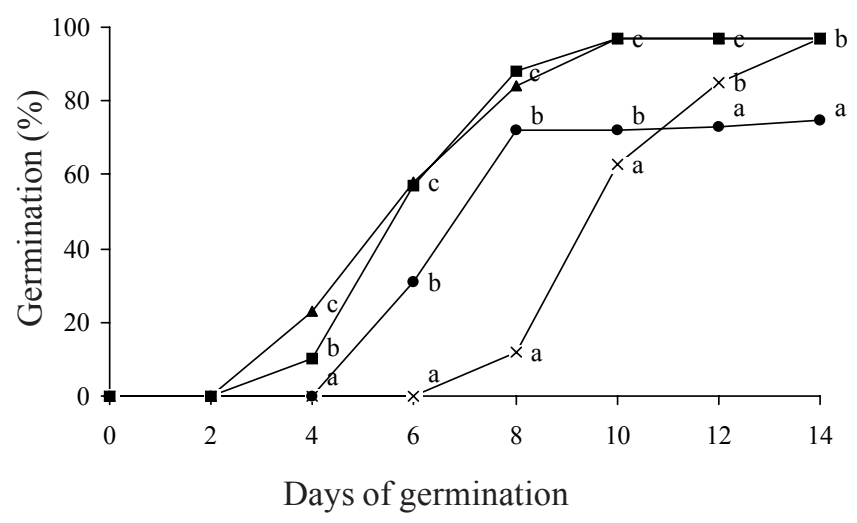

Figure 1. Effect of temperature on germination of spores of Rumohra adiantiformis in liquid Dyer medium, under a 16-h photoperiod in growth chamber: $15^{\circ} \mathrm{C}(\mathbf{x}), 20^{\circ} \mathrm{C}(\mathbf{\bullet}), 25^{\circ} \mathrm{C}$ $(\boldsymbol{\Delta}), 30^{\circ} \mathrm{C}(\bullet)$. Small letters denote statistical differences between treatments (Tukey test, $\mathrm{p}<0.05$ ).
Chr., liquid media were superior to solid media for early gametophyte development, but there was no effect on germination percentages. Camloh (1993, 1999) also reported that the best germination occurred when unsterilized spores of $P$. bifurcatum were used, but the contamination always occurred after 10 days of culture, which was probably the reason for the lower cell number as compared to sterilized spores. Simabukuro et al. (1998) comment that before storing imbibed spores in the laboratory or before germination of spores stored dry, there is the need to sterilize them. The same authors observed for Cyathea delgadii Sternb. that the elimination of bacterial and fungal contaminants was best when the spores were washed, treated with calcium hypochlorite, incubated, filtered and washed again before sowing on medium containing Nystatin.

The highest percentages of germination and the lowest mean germination time were observed at 15, 20 and $25 \pm 1{ }^{\circ} \mathrm{C}$ and the germination was partially inhibited at $30 \pm 1{ }^{\circ} \mathrm{C}$ (figure 1 , table 1). Therefore, the lowest mean germination time was observed at $25 \pm 1^{\circ} \mathrm{C}$ and

Table 1. The effect of temperature on mean germination time $(\overline{\mathrm{t}})$ of Rumohra adiantiformis under a 16-h photoperiod. Different letters denote statistical differences between treatments (Tukey test, $\mathrm{p}<0.05)$. i.c. $=$ interval of confidence; $\mathrm{c} . \mathrm{v}=$ coefficient of variation for percentage of germination; $\mathrm{s}^{2}=$ variance of mean time to complete germination.

\begin{tabular}{lccrc}
\hline $\mathrm{T}^{\circ} \mathrm{C}$ & $\begin{array}{c}\text { mean } \pm \text { i.c. } \\
\text { germination }(\%)\end{array}$ & c.v. & $\overline{\mathrm{t}}($ days $)$ & $\mathrm{s}^{2}$ \\
\hline $15 \pm 1$ & $96.5 \pm 0.56$ & 0.59 & $12.10 \mathrm{~d}$ & 0.0056 \\
$20 \pm 1$ & $97.0 \pm 0.80$ & 0.84 & $9.21 \mathrm{~b}$ & 0.0071 \\
$25 \pm 1$ & $97.5 \pm 0.48$ & 0.51 & $7.93 \mathrm{a}$ & 0.0026 \\
$30 \pm 1$ & $74.3 \pm 3.29$ & 6.38 & $10.63 \mathrm{c}$ & 0.0062 \\
\hline
\end{tabular}

the highest at $15 \pm 1{ }^{\circ} \mathrm{C}$, which means that the temperature analyzed in this paper providing the fastest germination is $25^{\circ} \mathrm{C}$, but spores can also germinate more slowly at 20 and $15 \pm 1{ }^{\circ} \mathrm{C}$. On the other hand, the germination was partially inhibited at $30^{\circ} \mathrm{C}$. The effect of temperatures on fern germination seems to affect light responses. High temperature followed by saturate red light irradiance inhibits spore germination in several fern species (Ranal 1999). Raghavan (1989) explains that high temperatures uncouple the phytochrome. Haupt (1991, 1992) observes that the phytochromemediated spore germination in Dryopteris filix-mas L. 
and $D$. paleacea is inhibited by raising the temperature from 22 to 27 or $32{ }^{\circ} \mathrm{C}$. The elevated temperature is effective during the "coupling phase" when the far-red phytochrome (Pfr) starts the processes leading to germination (Haupt 1990). It is generally accepted that Pfr starts a whole cascade of events, eventually culminating in gene-dependent protein synthesis as the immediate cause of the terminal response. The elevated temperature also inhibits the response if $\mathrm{Pfr}$ is permanently present, but under these conditions the inhibition is not total (Haupt 1990). Our data on $R$. adiantiformis germination are in accordance with these findings.

The germination of sterilized spores of $R$. adiantiformis was completely inhibited under $72 \%$ and $54 \%$ of total irradiance in March and partially inhibited under $72 \%$ of total irradiance in April (figure 2). The least mean germination time was achieved under 9\% total irradiance in April and August followed by $17 \%$ of total irradiance in August (table 2). The germination of $R$. adiantiformis was photoinhibited by high irradiance. The effect of irradiance on fern germination was also studied in Dicksonia sellowiana (Presl.) Hook. (Filippini et al. 1999). The lower percentages of germination were observed in spores kept under $43 \%$ and $2 \%$ of total irradiance, while those kept under $26 \%, 19 \%$ and $4 \%$ presented higher percentages. Seeds of many species which are light germinators can be inhibited by prolonged exposure to light, especially if the fluence is high. The photonhibition of seed germination is a manifestation of the high-irradiance reaction (HIR) according to Bewley \& Black (1994). The same authors suggest that photoinhibition is a mechanism for discouraging seed germination under high field irradiance when seedling would be subjected to harsh, drying conditions. Shinomura et al. (1996) explain that seed germination of light-sensitive species is a low fluence response (LFR) controlled by the detection of changes in the red far-red ratio (R/FR) through phytochrome B (Phy B). A similar photoinhibition behaviour could be proposed for spores of $R$. adiantiformis which could guarantee gametophyte growth and reproduction only in appropriate environmental conditions where abundant water supply, low irradiance and mild temperatures are available
A

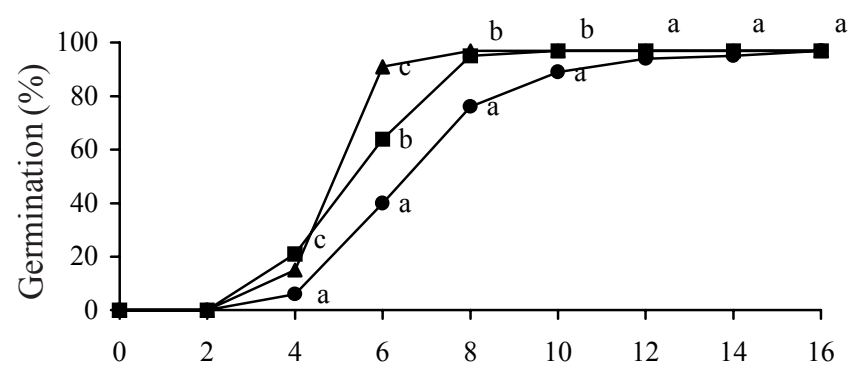

Days of germination

B

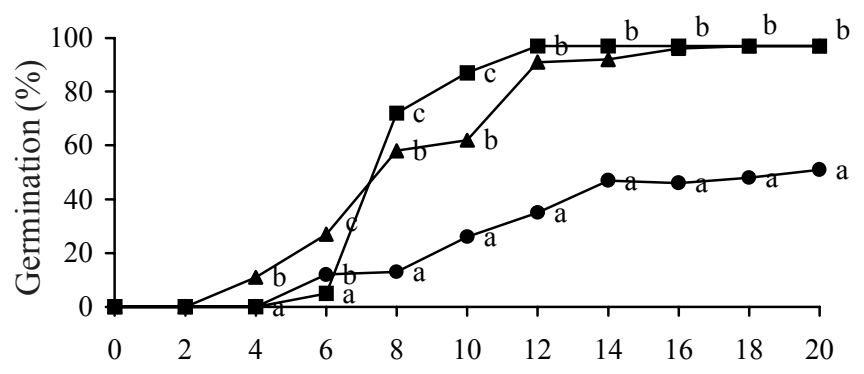

Days of germination

C

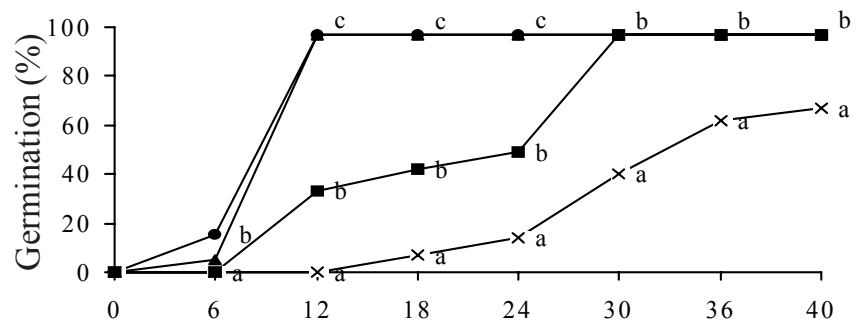

Days of germination

Figure 2. Germination of spores of Rumohra adiantiformis cultivated in Dyer mediam, under 9\%, 17\%, 54\% and $72 \%$ of total irradiance in field conditions. Germination under $9 \%$ (A) and $17 \%$ (B) of total irradiance in March (•), April ( $\mathbf{(})$ and August (-) 2000. Germination in April 2000 (C), under $9 \%(\bullet), 17 \%(\mathbf{\Delta}), 54 \%(\bullet)$ and $72 \%(\mathbf{x})$ of total irradiance. Small letters denote statistical differences between treatments (Tukey test, $\mathrm{p}<0.05$ ). 
Table 2. Effect of irradiance on mean germination time $(\overline{\mathrm{t}})$ of Rumohra adiantiformis. Different letters denote statistical differences between treatments (Tukey test, $\mathrm{p}<0.05$ ). i.c. $=$ interval of confidence; c.v. $=$ coefficient of variation for percentage of germination; $\mathrm{s}^{2}=$ variance of mean germination time. I-March 2000, II-April 2000, III-August 2000.

\begin{tabular}{cccccc}
\hline $\begin{array}{c}\text { Total } \\
\text { irradiance }(\%)\end{array}$ & Experiment & $\begin{array}{c}\text { Mean } \pm \text { i.c. } \\
\text { germination }(\%)\end{array}$ & c.v. & $\overline{\mathrm{t}}$ (days) & $\mathrm{s}^{2}$ \\
\hline 72 & I & 0 & - & - & - \\
72 & II & $67.37 \pm 1.92$ & 4.11 & $31.07 \mathrm{f}$ & 0.5845 \\
54 & I & 0 & - & - & - \\
54 & II & $97.25 \pm 0.93$ & 0.98 & $23.00 \mathrm{e}$ & 1.1694 \\
17 & I & $49.75 \pm 8.10$ & 23.5 & $14.45 \mathrm{~d}$ & 0.3680 \\
17 & II & $97.50 \pm 0.56$ & 0.98 & $14.14 \mathrm{~d}$ & 0.1155 \\
17 & III & $97.50 \pm 1.26$ & 1.32 & $10.12 \mathrm{~b}$ & 0.0010 \\
9 & I & $97.00 \pm 2.11$ & 2.22 & $11.62 \mathrm{c}$ & 0.0221 \\
9 & II & $97.25 \pm 0.93$ & 0.98 & $7.93 \mathrm{a}$ & 0.0057 \\
9 & III & $97.25 \pm 0.89$ & 0.98 & $8.80 \mathrm{a}$ & 0.0020 \\
\hline
\end{tabular}

Acknowledgements - We thank Rudinei Conte (agronomist) for collecting plant material, Dr. Maria Terezinha Silveira Paulilo for suggestions, and Robert J. Warren for revising the English manuscript.

\section{References}

BEWLEY, J.D. \& BLACK, M. 1994. Seeds: physiology of development and germination. $2^{\text {nd }}$ ed. Plennum Press, New York.

CAMLOH, M. 1993. Spore germination and early gametophyte development of Platycerium bifurcatum. American Fern Journal 83:79-85.

CAMLOH, M. 1999. Spore age and sterilization affects germination and early gametophyte development of Platycerium bifurcatum. American Fern Journal 89:124-132.

CHEN, C. \& IKUMA, H. 1979. Photocontrol of the germination of Onoclea spores. Plant Physiology 63:704-708.

DYER, A.F. 1979. The culture of fern gametophytes for experimental investigation. In The experimental biology of ferns (A.F. Dyer, ed.). Academic, London, p.253-305.

FILIPPINI, E.C.P., DUZ, S.R. \& RANDI, A.M.1999. Light and storage in the germination of spores of Dicksonia selowiana (Presl.) Hook., Dicksoniaceae. Revista Brasileira de Botânica 22:21-26.

FURUYA, M. 1983. Photomorphogenesis in ferns. In Photomorphogenesis (W. Shropshire Jr. \& H. Mohr, eds.). Encyclopedia of Plant Physiology. Springer, Berlin. p.569-600.
FURUYA, M. 1985. Photocontrol of spore germination and elementary process of development in fern gametophytes. Proceedings of the Royal Society 86:13-19.

HAUPT, W. 1990. Phytochrome-mediated fern-spore germination: inhibition by elevated temperatures. Photochemical Photobiology 52:57-9.

HAUPT, W. 1991. Phytochrome-controlled fern-spore germination: phase-specific modulation by elevated temperatures. Photochemical Photobiology 54: 811-818.

HAUPT, W. 1992. Phytochrome-mediated fern-spore germination: a temperature-sensitive phase in the transduction chain after action of Pfr. Journal of Plant Physiology 140:575-81.

KATO, M. 1974. A note on the systematic position of Rumohra adiantiformis. Acta of Phytotaxonomy and Geobotany 26:52-57.

LABOURIAU, L.G. 1983. A germinação das sementes. Série de Biologia, Monografia 24. Programa Regional de Desenvolvimento Científico e Tecnológico. Secretaria Geral da Organização dos Estados Americanos, Washington.

MILTON, S.J. \& MOLL, E.J. 1988. Effects of harvesting on frond production of Rumohra adiantiformis (Pteridophyta: Aspidiaceae) in South Africa. Journal of Applied Ecology 25:725-43.

MOHR, H. 1956. Die Abängikeit des Protonemawatchstums und der Protonemapolarität bei farmen vom licht. Planta 47:127-156.

RAGHAVAN, V. 1989. Developmental biology of fern gametophytes. Cambridge University Press, Cambridge. 
RAGHAVAN, V. 1993. Cellular and molecular biology of fern haplophase development. Journal of Plant Research (Special issue) 3:59-73.

RANAL, M.A. 1999. Effects of temperature on spore germination in some fern species from semideciduous mesophytic forest. American Fern Journal 89:149-158.

SANTANA, D.G. \& RANAL, M. A. 2000. Análise estatísitica na germinação. Revista Brasileira de Fisiologia Vegetal (Edição especial) 12:205-237.

SHINOMURA, T., NAGATANI, A., HANZAWA, H., KUBOTA, M., WATANABE, M. \& FURUYA, M. 1996. Action spectra for phytochrome A and phytochrome B specific photoinduction of seed germination in Arabidopsis thaliana. Proceedings of the National Academy of Sciences 93:8129-8133.
SIMABUKURO, E.A., DYER, A.F. \& FELIPPE, G.M. 1998. The effect of sterilization and storage conditions on the viability of spores of Cyathea delgadii. American Fern Journal 88:124-132.

STAMPS, R.H., NELL, T.A. \& BARRET, J.E. 1994. Production temperatures influence growth and physiology of leatherleaf fern. HortScience 29:67-70.

TOWILL, L.R. 1978. Temperature and photocontrol of Onoclea spore germination. Plant Physiology 62:116-119.

TRYON, R. \& TRYON, A.F. 1982. Rumohra. In Fern and allied plants with special reference to Tropical America (R. Tryon \& A.F. Tryon, eds.). Springer, New York, p.487- 490 . 